\title{
PENGARUH MEDIA MASSA TERHADAP TAHAP PERKEMBANGAN PSIKOLOGI AGAMA PADA MANUSIA
}

\author{
Hari Harsananda ${ }^{1}$ Ida Bagus Subrahmaniam Saitya ${ }^{2}$ \\ Universitas Hindu Negeri I Gusti Bagus Sugriwa Denpasar
}

\begin{abstract}
The presence of mass media in the current era of globalization is nothing special, various kinds of media appear, grow and develop like mushrooms in the rainy season, especially with the internet that allows connections between individuals in this world. The media enter into people's lives and have an influence on one's beliefs, this is in line with the opinion of Jhon Vivian who said that mass media is a facility that carries messages to the public. A person's religious behavior arises because of an internal urge, which then gets an influence from the environment. In subsequent developments, religious behavior is much influenced by factors of religious experience, personality, psychological elements and others. Human life experiences several phases in the level of development of the religious soul in itself, including the children's phase, the adolescent phase, the adult phase, and the advanced phase. Each phase has its own characteristics and uniqueness. One of the formers of religious character in these phases is the mass media. Mass media in the present era is not only a complement but also a part of life. This media has both positive and negative influences on humans.
\end{abstract}

Keywords mass media; religious psychology.

\section{PENDAHULUAN}

Manusia merupakan mahkluk yang kompleks, dengan pikirannya manusia berkarya membuat sesuatu yang dapat membantu melengkapi kebutuhan hidupnya, mulai dari tata cara mencari dan membuat makanan, membuat tempat tinggal hingga memenuhi kebutuhan pelengkap kehidupan

\footnotetext{
${ }^{1}$ hariharsananda@gmail.com

2 idabagussubrahmaniamsaitya@gmail.com
}

seperti informasi dan hiburan. Kehadiran media massa di era globalisasi sekarang bukanlah hal yang spesial, berbagai macam media muncul, bertumbuh dan berkembang bagai jamur di musim hujan, apalagi dengan adanya internet yang mengijinkan koneksi antar individu di dunia ini. Tidak seperti 2 dekade lalu yang dimana media hanya 
sebagai sarana menghibur masyarakat dari kejenuhan aktivitas, kini media hadir dalam berbagai pola dan konsep yang tidak hanya sebagai sarana hiburan masyarakat, juga dapat menjadi sarana edukasi, kampanye politik, hingga sebagai sarana penyebaran hal - hal atau konten pornografi yang dapat merusak moral manusia, pada dekade inilah media sangat memberi pengaruh pada seseorang baik itu secara ideologi, gaya hidup hingga kiblat keberagamaan, maka dari itulah pada akan dibahas, mengenai bagaimana tahapan perkembangan psikologi agama pada manusia dan bagaimana media masuk dalam kehidupan masyarakat dan memberi pengaruh pada keyakinan seseorang hal ini senada dengan pendapat Jhon Vivian yang menuturkan dalam bukunya Teori Komunikasi Massa (2008: 453), media massa (mass media) merupakan fasilitas yang membawa pesan pada khalayak.

\section{METODE}

Menurut Moleong (2014) penelitian kualitatif adalah penelitian yang bermaksud untuk memahami fenomena tentang apa yang dialami oleh subjek penelitian misalnya perilaku, persepsi, motivasi, tindakan, secara holistik, dan dengan cara deskripsi dalam bentuk kata-kata dan bahasa pada suatu konteks khusus yang alamiah dan dengan memanfaatkan berbagai metode alamiah.

Teknik pengumpulan data yang digunakan, yaitu studi dokumen dan studi kepustakaan. Studi kepustakaan mencari sumber-sumber untuk penulusuran teksteks, naskah-naskah, buku-buku yang berkaitan dengan penelitian yang diteliti dari berbagai tempat. Menurut Moleong (2014) dokumen sudah lama digunakan dalam penelitian sebagai sumber data karena dalam banyak hal dokumen sebagai sumber data dimanfaatkan untuk menguji, menafsirkan, bahkan untuk meramalkan. Teknik analisis data yang digunakan berupak reduksi data, klasifikasi data, display data, dan penarikan kesimpulan.

\section{PEMBAHASAN}

\section{Tahap Perkembangan Jiwa Keagamaan Pada Manusia}

Manusia adalah makhluk yang memiliki banyak kebutuhan dalam hidupnya, salah satunya adalah kebutuhan akan agama. Berbagai pendapat tentang munculnya jiwa keagamaan dalam diri manusia dikemukakan oleh para ahli. Adanya rasa takut, rasa berdosa, rasa ketergantungan, hingga pengharapan akan masa depan menjadi alasan manusia membutuhkan agama. Dengan demikian tingkah laku keagamaan seseorang timbul karena dorongan dari dalam diri, yang kemudian mendapat pengaruh dari lingkungan. Dalam perkembangan selanjutnya, tingkah laku keagamaan banyak dipengaruhi oleh faktor pengalaman keagamaan, kepribadian, unsur kejiwaan dan lainnya.

Perkembangan jiwa keagamaan dalam diri seseorang berjalan selaras dengan kebutuhan dan tingkat usia manusia. Bertambahnya umur serta pertumbuhan fisik yang semakin dewasa beriringan dengan keadaan psikis yang semakin matang dan stabil. Dengan demikian, dalam kehidupannya, manusia mengalami beberapa fase tingkat perkembangan jiwa keagamaan dalam dirinya. Fase-fase tersebut adalah sebagai berikut:

\section{Tahap Anak-anak}

Psikologi Agama dalam pengertian secara umum dapat berarti suatu ilmu yang mempelajari tingkah laku manusia dalam WIDYA DUTA | VOL. 16, NO. 1 |2021 
hubungan dengan pengaruh keyakinan terhadap Agama yang dianutnya serta dalam kaitannya dengan pengaruh usia masingmasing. Menitikberatkan pada pemahaman keyakinan dalam beragama seharusnya dapat diberikan dengan klasifikasi dari jenjang usia anak tersebut, yang dapat disebut dengan anak-anak adalah rentan usia dari 1-11 tahun, karena pada masa inilah kedua orang tua memiliki peranan penuh terhadap perkembangan jiwa keagamaan pada anak tersebut. Menuntun dan membimbing anak tersebut untuk mengetahui secara gambaran umum ataupun pengenalan tentang keagamaan mereka.

Masa kanak-kanak adalah masa dimana seorang individu (anak) mulai dapat berinteraksi dengan individu yang lainnya, pada masa inilah sebenarnya masa emas dimana seseorang diperkenalkan dengan Agama, karena pada masa ini anak yang secara pikiran belum terlalu kritis dalam artian setiap apa yang diberikan oleh orang tuanya akan diterimanya begitu saja. Adapun perkembangan keagamaan seorang individu (anak) terdapat factor-faktor yang tentunya mempengaruhi proses keagamaannya, seperti factor internal maupun eksternal (luar dirinya).

Menurut Erik Erikson (dalam Danim, 2010: 39) berpendapat bahwa tugas utama anak-anak selama tahap psikososial (pengenalan diri mereka) dalam kehidupan pertamanya adalah belajar mempercayai orang yang merawat atau mengasuhnya. Ketika mereka membentuk hubungan dan mengembangkan rasa mengorganisasikan diri pada tahap awal, kemudian segera mengembangkan dimensi sosialnya, termasuk menunjukkan perilaku untuk membantu, bekerja sama dengan orang lain. Pada fase ini kepribadiannya mulai terbentuk menjadi modal awal baginya ketika memasuki usia sekolah.

Adapun perkembangan Agama pada anak-anak terdiri dari dua tingkatan yakni : 1) tingkat pertama dimulai pada anak berusia 36 tahun. Pada tingkatan ini konsep mengenai Tuhan lebih banyak dipengaruhi oleh fantasi dan emosi. Pada tingkat perkembangan ini anak menghayati konsep ketuhanan sesuai dengan tingkat perkembangan intelektualnya. Kehidupan masa ini masih banyak dipengaruhi kehidupan fantasi sehingga dalam menanggapi Agama pun anak masih menggunakan konsep fantasi yang dijelaskan melalui media seperti dongengdongeng tentang ketuhanan yang tentunya dapat memberikan gambara awal mengenai pemahaman keagamaan terhadap anak.

Pemahaman awal mengenal Agama biasanya dapat dilakukan ketika anak tersebut mangenyam tahun-tahun prasekolah atau menjalani Pendidikan Anak Usia Dini (PAUD). Pendidikan anak usia dini (PAUD) merupakan pembinaan dan pengembangan yang ditujukan kepada anak sejak lahir sampai usia enam tahun. Adapun kegiatan yang dilakukan adalah dengan memberikan rangsangan pendidikan untuk membantu pertumbuhan dan perkembangan jasmani dan rohani agar anak tersebut memiliki kesiapan dalam memasuki pendidikan lebih lanjut. Pada umumnya halhal yang dilakukan anak ketika berusia 3-6 tahun adalah untuk mengembangkan ketrampilannya, antara lain :

- Mengamati perilaku orang lain,

- Membentuk citra mental dari prilaku itu,

- Meniru prilaku tersebut,

- Praktik perilaku, dan 
- Termotivasi untuk mengulangi perilaku tersebut (Danim, 2010 : 45).

Dengan gambaran seperti itu, maka hal yang memang baik dilaksanakan pada usia 3-6 tahun tersebut adalah mengembangkan ajaran tentang keagamaan awal ataupun memberikan penjelasan awal mengenai pentingnya menghargai orang lain selalu berkata, berbuat dan perfikir yang baik sesuai dengan ajaran Hindu yang disebut dengan Tri Kaya Parisudha, sehingga apa yang dijelaskan dapat dimengerti oleh anak sehingga secara tidak langsung menanamkan nilai Agama pada anak sudah dapat dilakukan dah bahkan cenderung akan ditiru oleh si anak pada praktek sehari-harinya.

Tingkatan selanjutnya pada proses pemahaman Agama pada anak dilaksanakan pada saat memasuki jenjang Sekolah Dasar (SD) antara usia 6-12 tahun. Pada masa ini secara tidak langsung ide ketuhanan anak sudah mencerminkan konsep-konsep yang berdasarkan kepada kenyataan. Konsep ini timbul melalui lembaga-lembaga keagamaan dan pengajaran Agama dari gurunya. Melalui lembaga-lembaga keagamaan pada anak didasarkan atas dorongan emosiaonal, sehingga mereka dapat melahirkan konsep Tuhan sesuai dengan pemahaman mereka. Pada masa ini cenderung anak tersebut akan tertarik dengan lembaga keagamaan yang mereka lihat dikelola oleh guru Agamanya tersebut.

Pada fase ataupun tahap akhir dari usia anak-anak dan akan masuk ke dalam jenjang usia selanjutnya, pada masa ini pemahaman Agama seharusnya diberikan lebih dalam sehingga dalam diri anak tersebut sudah tertanam bagaimana ajaranajaran Agama nya dapat dipraktekkan langsung dalam kehidupan nyata mereka.
Anak usia 6-12 cenderung mulai aktif untuk mencoba-coba sesuatu yang baru, pada saat inilah seharusnya untuk meningkatkan jiwa keagamaan pada anak, diberikanlah pemahaman dasar pada anak tersebut dengan menjelaskan beberapa ajaran-ajaran Agama yang tentunya dapat mereka lihat disekelilingnya seperti konsep Tri Hita Karana (Tiga penyebab kebahagiaan hidup di dunia ini), yang paling sederhana adalah konsep hormat kepada Catur Guru yakni Guru Rupaka, Guru Pengajian, Guru Wisesa, dan Guru Swadhyaya, serta menanamkan pengetahuan tentang konsep Ahimsa, Karma Phala dan Dewa-Dewa dalam Agama Hindu.

Dalam perkembangannya seorang individu (anak) juga harus ditanamkan pengetahuan agar tidak melupakan kewajiban sebagai seorang anak ataupun seorang murid, karena tanpa adanya orang tua dan guru pengajian, maka anak tersebut tidak akan bisa membedakan mana hal yang baik dan mana hal yang buruk yang harus dilakukan dalam hidup ini (Asmariani, 51 : 2010). Adapun pemahaman ajaran Agama bagaimana seorang anak sepatutnya berbhakti kepada kedua orang tuanya dijelaskan dalam kitab Manava Dharmasastra, sebagai berikut :

Tayor nityam priyam kuryad

Acharyasya ca sarvada,

Tesyeva trisu tustesu

Tapah sarvam samapyate.

Terjemahannya :

Seorang anak harus selalu melakukan apa yang disetujui oleh kedua orang tuanya dan apa yang menyenangkan gurunya, kalau ketiga orang itu senang ia mendapatkan segala pahala dari tapa bratanya (Pudja, 1973: 86).

WIDYA DUTA | VOL. 16, NO. 1 |2021 


\section{Tahap Remaja}

Seperti yang diketahui bahwa jiwa manusia bersifat abstrak, oleh karena itu hal tersebut hanya mungkin dilihat dan dipelajari dari hal yang tampak yaitu dari sikap dan tingkah laku manusia itu sendiri. Mengenai pembahasan sub bab ini, remaja menjadi fokus perhatian. Sesuai dengan pernyataan Thouless mengenai psikologi agama, yang menyatakan bahwa suatu psikologi agama menunjukkan suatu cara penyesuaian diri terhadap dunia yang mencakup lebih luas dari lingkungan dunia fisik yang terikat ruang dan waktu, maka suatu psikologi keagamaan remaja yang menginjak usia peralihan (Termasuk dalam tahap progresif pada pembagian tahap perkembangan manusia) juga mencakup perkebangan jasmani dan rohani yang turut dipengaruhi oleh juvebilitas (adolescantinum), pubertas, dan nubilitas. Penghayatan terhadap suatu agama dan penerapannya sangat dipegaruhi oleh faktorfaktor tersebut. Sehingga perkembangan agama pada remaja ditandai dengan adanya beberapa faktor perkembangan jasmani dan rohaninya.

Adapun perkembangan jasmani dan rohani itu dijelaskan menurut $W$. Starbuck (Jalaluddin, 2015: 65) antara lain sebagai berikut :

a. Pertumbuhan Pikiran dan
Mental

Perkembangan pikiran dan mental keagamaan mempengaruhi sikap keagamaan para remaja. Seiring perkembangan usia, halhal yang diterima saat kanak-kanak mulai dipertanyakan sehingga menimbulkan sikap kritis terhadap ajaran-ajaran agama, selain masalah agama, mereka juga tertarik dengan persoalan-persoalan budaya, sosial, ekonomi, dan norma-norma kehidupan lainnya. Dalam tatanan ini agama-agama yang bersifat konservatif-dogmatis lebih kuat mempengaruhi remaja untuk tetap taat dengan ajaran agamanya, sedangkan sebaliknya agama yang lebih bersifat liberal akan lebih mudah merangsang perkebangan pikiran remaja sehingga akan lebih mudah untuk meninggalkan agamanya.

\section{Perkembangan Perasaan}

Terdapat perasaan sosial, etis, dan estetis dalam perkembangan perasaan remaja dalam peranannya menghyati kehidupan yang dilkukan dalam lingkungannya, bila seseorang terbiasa sehari-hari mendapat siraman rohani maka perasaan yang muncul yang mendorongnya untuk bertingkahlaku maka ke-arah yang religius juga, sebaiknya bagi remaja yang jarang atau kurag mendapatkan ajaran keagamaan dan siraman rohani akan cenderung mudah didominasi oleh dorongan seksual karena keingin tahuan remaja sangat besar dan perasaan super itu sendiri memegang peran yang signifikan.

\section{Pertimbangan Sosial}

Muncul perimbangan antara moral dan materil. Remaja mengalami konflik dalam menentukan pilihan tersebut, namun karena kehidupan di dunia sangat terkait dengan materi, maka mengakibatkan remaja memilih kecenderungan dengan jiwa yang materialistis, dimana pemikiran remaja sesuai penyelidikan Ernest Harm terhadap 1.789 remaja di Amerika antara usia 18-29 tahun menunjukkan bahwa; $70 \%$ pemikiran remaja ditunjukkan bagi kepentingan keuangan, kesejahteraan, kebahagiaan, kehormatan diri, dan masalah kesenangan pribadi lainnya, sedangkan masalah akhirat 
dan keagamaan hanya sekitar 3,6\%, masalah sosial $3,8 \%$.

\section{Perkembangan Moral}

Perkembangan moral pada remaja bertitik tolak dari rasa berdosa dan usaha untuk mencari proteksi, adapun tipe moral yang juga terdapat pada remaja mencakup:

1. Self-directive, taat pada moral atau agama berdasarkan pertimbangan pribadi.

2. Adaptive, menikuti situasi lingkungan tanpa mengadakan kritik.

3. Submissive, merasaka adanya keraguan terhadap ajaran moral dan agama.

4. Unadjusted, belum meyakini akan kebenaran ajaran agama dan moral.

5. Deviant, menolak dasar hukum keagamaan serta tatanan moral masyarakat.

\section{Sikap dan Minat}

Sikap dan minat terhadap masalah keagamaan sangat dipengaruhi oleh faktor lingkungan yang ia tinggali sehari-hari, tergantung dari siraman-siraman keagamaan dari keluarga, pendidikan formal maupun informal sebagai suatu kebiasaan semasa kecil hingga remaja. Hal itu sesuai dengan pernyataan Titib yang menyatakan bahwa Perkembangan sikap keagamaan tersebut dapat diimbangi dengan aspek moralitas dalam agama sebagai sumber pendidikan budi pekerti baik yang dipancarkan dalam keluarga, sekolah, maupun masyarakat (Titib, 2003: 91).

\section{Ibadah}

Adanya pandangan bahwa sembahyang tersebut merupakan sebagai suatu manfaat untuk berkomunikasi dengan
Tuhan, dan pandangan bahwa sembahyang tersebut merpakan sebgai suatu media bermeditasi.

\section{Tahap Dewasa}

Orang dewasa adalah seseorang yang telah mencapai tingkat kematangan secara kognitif, afektif maupun psikomotor. Dengan kata lain, orang dewasa adalah orang yang secara fisik telah tumbuh dengan sempurna dan secara psikologi telah matang sehingga dapat bertanggung jawab terhadap dirinya dan orang lain. Keadaan tersebut biasanya dicapai pada umur sekitar 20 tahun. Idealnya kedewasaan secara fisik akan diikuti oleh kematangan secara psikis. Namun sering dijumpai seseorang yang telah dewasa secara jasmani namun belum matang dalam psikis atau rohaninya, begitu pula sebaliknya.hal tersebut disebabkan oleh banyak factor seperti bakat, hambatan mental, dan lain sebagainya.

Orang dewasa telah memiliki identitas yang jelas dan kepribadian yang mantap. Identitas dan kepribadian tersebut dibentuk oleh pemahaman terhadap nilainilai yang dianutnya serta usaha dalam mempertahankan nilai-nilai tersebut. Dalam fase dewasa, manusia telah memahami makna kehidupan dan memiliki tanggung jawab, baik berupa tanggung jawab sosial, moral, ekonomi, agama dan lainnya. Karena itu, sikap keberagamaan seseorang yang telah dewasa cenderung didasarkan atas pemilihan terhadap ajaran agama yang dapat memberikan kepuasan batin atas dasar pertimbangan akal sehat.

Kemantapan jiwa orang dewasa memberikan gambaran tentang bagaimana sikap keberagamaan pada orang dewasa. Bertambahnya wawasan dan stabilnya mental serta emosi memberikan kontribusi

WIDYA DUTA | VOL. 16, NO. 1 |2021 
terhadap pembentukan sikap keberagamaan orang dewasa. Sikap keberagamaan itu akan dipertahankan sebagai identitas dan kepribadian dan membawa mereka secara mantap menjalankan ajaran agama yang mereka anut. Tidak jarang sikap keberagamaan tersebut dapat menimbulkan ketaatan yang berlebihan dan menjurus pada sikap fanatisme. Namun, orang dewasa yang memantapkan diri terhadap nilai universal dapat menunjukkan sikap keberagamaan yang terbuka, toleransi dan saling menghargai nilai yang dianut oleh orang lain.

Seorang yang telah memasuki fase dewasa sudah memiliki tanggung jawab terhadap sistem nilai yang dipilihnya, baik nilai yang bersumber dari ajaran agama maupun yang bersumber dari norma-norma lain dalam kehidupan. Intinya, pemilihan nilai-nilai tersebut didasarkan atas pertimbangan pemikiran yang matang. Berdasarkan hal ini maka sikap keberagamaan seorang di usia dewasa sulit untuk diubah. Jika pun terjadi perubahan mungkin proses itu terjadi setelah didasarkan atas pertimbangan yang matang.

Sikap keberagamaan orang dewasa pada umumnya dilandasi oleh pendalaman dan perluasan terhadap ajaran agama yang dianutnya. Orang dewasa yang memiliki kemantapan terhadap nilai-nilai agama yang dianggap sesuai dengan kebutuhan dan latar belakang kehidupannya akan dipertahankan sedemikian rupa. Mendalami nilai tersebut, mengamalkannya bahkan hingga menyebarkan nilai tersebut merupakan tindakan untuk mempertahankan eksistensi nilai agama yang dianutnya. Begitu juga halnya, jika seorang dewasa memilih nilai yang bersumber dari nilai-nilai nonagama, itu pun akan dipertahankannya sebagai pandangan hidupnya. Jika mempertahankan nilai agama kemungkinan dapat menimbulkan fanatisme, maka dalam usaha mempertahankan nilai nonagama dapat memberi peluang bagi munculnya kecenderungan sikap yang antiagama. Sikap tersebut timbul apabila menurut pertimbangan akal sehat (commonsense), terdapat kelemahan-kelemahan tertentu dalam ajaran agama yang dipahaminya. Bahkan tak jarang sikap antiagama seperti itu diperlihatkannya dalam bentuk sikap menolak hingga ke tindakan memusuhi agama yang dinilainya mengikat dan bersifat dogmatis.

Sejalan dengan tingkat perkembangan usianya, maka sikap keberagamaan pada orang dewasa menurut Jalaluddin (2016: 95) antara lain memiliki ciriciri sebagai berikut.

1. Menerima kebenaran agama berdasarkan pertimbangan pemikiran yang matang, bukan sekadar ikut-ikutan.

2. cenderung bersifat realis, sehingga norma-norma agama lebih banyak diaplikasikan dalam sikap dan tingkah laku

3. Bersikap positif terhadap ajaran dan norma-norma agama, dan berusaha untuk mempelajari dan memperdalam pemahaman keagamaan

4. Tingkat ketaatan beragama didasarkan atas pertimbangan dan tanggung jawab diri hingga sikap keberagamaan merupakan realisasi dari sikap hidup

5. Bersikap lebih terbuka dan wawasan yang lebih luas

6. Bersikap lebih kritis terhadap materi ajaran agama sehingga ke mantapan beragama selain didasarkan atas 
pertimbangan pikiran, ju didasarkan atas pertimbangan hati nurani tipetipe ke keberagamaan cenderung mengarah kepada

7. Sikap adanya pengaruhkepribadian badian masing-masing, sehingga terlihat ajaran agama yang dalam menerima, memahami serta melaksanakan diyakininya. keberagamaan dengan

8. Terlihat adanya hubungan antara sikap kepentingan organisasi kehidupan sosial, sehingga perhatian terhadap sosial keagamaan sudah berkembang.

\section{Tahap Lanjut}

Tahap lanjut, atau dewasa lanjutan dimulai dari umur 65 tahun keatas. Menurut Rita Atkinson (dalam Jalaluddin, 2016: 96), manusia mencapai puncak periode usia yang paling produktif pada tahap kedewasaan menengah (40 - 65 tahun). Tetapi,dalam hubungan dengan kejiwaan, pada usia ini terjadi krisis akibat pertentang batin antara keinginan untuk bangkit dengan kemunduran diri. Karena itu, umumnya pemikiran mereka tertuju kepada upaya untuk kepentingan keluarga, masyarakat, dan generasi mendatang.

Seseorang yang telah berusia di atas 65 tahunakan menghadapi sejumlah permasalahan. Permasalahan pertama adalah penurunan kemampuan fisik yang berdampak pada berkurangnya kekuatan fisik, aktivitas menurun, sering mengalami gangguan kesehatan yang menyebabkan mereka kehilangan semangat. Pengaruh dari kondisi penurunan kemampuan fisik ini menyebabkan mereka yang berada pada usia lanjut merasa dirinya sudah tidak berharga atau kurang dihargai. Karena itu, mereka cenderung mengingat sukses masa lalu, sehingga umumnya mereka yang berada pada tingkat usia lanjut ini senang membantu para remaja yang aktif dalam kegiatankegiatan sosial termasuk sosial keagamaan.

Orang yang telah berada di usia lanjut dianggap telah memiliki banyak pengetahuan dan berbagai pengalaman yang mengasah jiwa keberagamaannya. Dalam menjalankan aktivitas keagamaan, mereka cenderung berperan sebagai penuntun atau guru bagi para generasi dibawahnya. Dalam hal ini, proses pewarisan nilai-nilai terjadi kepada generasi yang lebih muda. Para orang yang berusia lanjut (orang tua) merupakan figur contoh di dalam masyarakat. Mereka diberi gelar sesepuh atau tetua yang menandakan penghormatan terhadap kebijaksanaan yang didapatkan dari kematangan psikologis atau jiwa keberagamaanya.

Para ahli psikologi sering berpendapat bahwa sikap keagamaan seseorang ikut dipengaruhi oleh tingkatusia. Pertumbuhan jasmani mengalami penurunan menjelang manusia menapak usia senjanya. Proses penurunan kemampuan fisik ini ikut memberi pengaruh dalam perkembangan psikis, khususnya yang terkait dengan aspek spiritualitas. Namun, pengaruh itu berlaku sebaliknya, yakni terjadi peningkatan pada nilai-nilai spiritual. Seakan kelemahan fisik mendorong manusia untuk memperkuat spiritualitasnya sebagai kompensasi. Meningkatnya spiritualitas berdampak menurunnya sikap egoistis sehingga orang yang berada ada usia ini menunjukkan kecenderungan untuk menerima pendapat orang lain menjadi semakin meningkat.

Peningkatan kehidupan keagamaan yang dialami oleh orang berusia lanjut,olehpara ahli psikologi sering dihubungkan dengan penurunan kegairahan WIDYA DUTA | VOL. 16, NO. 1 |2021 
seksual. Menurut pendukung pendapat ini manusia usia lanjut mengalami frustasi di bidang seksual, sejalan dengan penurunan fisik dan frustasi semacam itu dinilai sebagai satu-satunya faktor yang sikap keagamaan. Pendapat tersebut nampaknya memiliki korelasi positif dengan pola kehidupan para tokoh agamawan seperti biksu, biarawan, pendeta dan lain sebagainya yang menghindari kehidupan seksual. Sehingga pada umumnya, para agamawan adalah mereka yang telah berada pada usia senja atau dewasa lanjutan.

Pada dasarnya sikap keberagamaan pada masa lanjut sangat dipengaruhi oleh kesenjangan antara jasmani dan rohani. Selain itu kesadaran akan mendekatnya kematian menjadi factor lain yang mendorong meningkatnya kematangan jiwa beragama. Menyadari kelemahan jasmani mengantarkan seseorang lebih dekat kepada Tuhan sebagai kausa prima. Ajaran-ajaran agama yang memberikan harapan tentang kehidupan abadi setelah kematian menjadi objek utama bagi mereka yang telah berusia lanjut.

Berbagai latar belakang yang dikemukakan di atas menjadi penyebab kecenderungan sikap keagamaan pada manusia usia lanjutturut memberi gambaran tentang ciri-ciri keberagamaan mereka. Secara garis besarnya menurut Jalaluddin (2016: 100) ciri-ciri keberagamaan pada usia lanjut adalah

1. Kehidupan keagamaan pada usia lanjut sudah menca tingkat kemantapan

2. Meningkatnya kecenderungan untuk menerima pendapat keagamaan.

3. Mulai muncul pengakuan terhadap realitas tentang kehidupan akhirat secara lebih sungguh-sungguh
4. Sikap keagamaan cenderung mengarah kepada butuhan saling cinta antarsesama manusia, serta sifat-sifat luhur.

5. Timbul rasa takut kepada kematian yang meningkat sejalan dengan pertambahan usia lanjutnya

6. Perasan takut kepada kematian ini berdampak pada peningkatan pembentukan sikap keagamaan dan kepercayaan terhadap adanya kehidupan abadi(akhirat)

Dari uraian di atas dapat diketahui bahwa kematangan jiwa keberagama manusia memiliki empat fase perkembangan. Di dalam agama Hindu memiliki konsep catur asrama yang juga membagi tingkat kematangan jiwa seseorang kedalam empat fase. Catur asrama berasal dari kata catur yang berarti empat dan asrama yang berarti jenjang hidup. Jadi catur asrama berarti empat jenjang hidup yang dijalani oleh manusia (tim penyusun, 2005). Catur asrama terdiri dari brahmacari yaitu masa belajar atau menuntut ilmu, grhastha adalah masa berumah tangga, wanaprastha masa pengasingan diri dan mulai meninggalkan ikatan duniawi, dan terakhir bhiksuka yaitu masa menyempurnakan tingkat spiritualitas. Konsep catur asrama dibagi berdasarkan kewajiban yang harus dijalani oleh seseorang semasa hidupnya. menjalani kewajiban dan memenuhi tanggungjawab tentu mempengaruhi aktifitas keagamaan dan kematangan jiwa beragama seseorang.

Jika dibandingkan dengan keempat fase kematangan jiwa keberagamaan di atas dengan konsep catur asrama di dalam agama Hindu, fase anak-anak dan remaja yang dicirikan dengan tingginya rasa ingin tahu dan keadaan mental yang belum matang dapat 
disebandingkan dengan masa brahmacari. Fase dewasa yang mulai memiliki kematangan jasmani dan rohani, kecenderungan untuk berkeluarga dan melakukan kegiatan sosial sama dengan masa grhastha. Dan fase usia lanjut yang mulai mengalami kelemahan fisik namun meningkat secara spiritual sesuai dengan masa wanaprastha hingga bhiksuka. Fase terakhir merupakan puncak kematangan jiwa spiritual manusia. Melemahnya tubuh fisik menuntun seseorang untuk lebih banyak melakukan introspeksi diri dan menemukan kebijaksanaan di dalam

\section{Media Massa dan Pengaruhnya pada Psikologi Agama}

\section{Pengertian Media Massa}

Selain pendapat dari john Vivian

diatas, menurut Cangara (2003:132), media merupakan alat atau fasilitas yang dipakai untuk mengemukakan pesan dari komunikator pada khalayak, sedang pengertian media massa sendiri alat yang dipakai dalam penyampaian pesan dari sumber pada khalayak dengan memakai alatalat komunikasi seperti surat kabar, film, radio serta tv. Selanjutnya, media massa memiliki beberapa karakteristik sebagaimana diungkapkan oleh Cangara sebagai berikut (Cangara, 2003:134):

1. Bersifat melembaga: pihak yang mengelola media terdiri atas banyak orang, yakni mulai dari pengumpulan, pengelolaan, sampai pada penyajian informasi.

2. Bersifat satu arah: komunikasi yang dilakukan kurang memungkinkan terjadinya dialog antara pengirim dengan penerima. Kalau misalnya terjadi reaksi atau umpan balik maka biasanya memerlukan waktu dan tertunda.

3. Meluas dan serempak: dapat mengatasi rintangan waktu dan jarak karena memiliki kecepatan. Bergerak secara luas dan simultan, di mana informasi yang disampaikan diterima oleh banyak orang pada saat yang sama.

4. Memakai peralatan teknis atau mekanis: seperti radio, televisi, surat kabar, dan semacamnya.

5. Bersifat terbuka: pesan dapat diterima oleh siapa saja dan di mana saja tanpa mengenal usia, jenis kelamin, agama, dan suku bangsa. Beberapa bentuk media massa meliputi alat-alat komunikasi mekanis seperti surat kabar, film,radio, dan televisi.

Lebih lanjut lagi menurut Mc.Quail. (1994:70) media massa memiliki fungsi sebagai berikut

1. Informasi

Menyediakan informasi tentang peristiwa dan kondisi dalam masyarakat dan dunia Menunjukkan, hubungan kekuasaan, Memudahkan inovasi adaptasi dan kemajuan.

2. Korelasi

Menjelaskan, menafsirkan, mengomentari makna peristiwa dan informasi, menunjang otoritas dan norma-norma yang mapan, melakukan sosialisasi, mengkoordinasikan ngbeberapa kegiatan, membentuk kesepakatan, menentukan urutan prioritas dan memberikan status relaif.

3. Kesinambungan

Mengekspresikan budaya dominant dan mengakui keberadaan

WIDYA DUTA | VOL. 16, NO. 1 |2021 
kebudayaan khusus (subculture) serta perkembangan budaya baru, meningkatkan dan melestarikan nilai-nilai.

4. Hiburan

Menyediakan hiburan, pengalihan perhatian dan sarana relaksasi, meredakan ketegangan sosial.

5. Mobilisasi

Mengkampenyakan tujuan masyarakat dalam bidang politik, pembangunan, ekonomi, pekerjaan dan agama.

Media massa akan sangat bermanfaat jika fungsi - fungsi diatas dapat berjalan dengan baik dengan penayangan konten yang berimbang, namun dengan adanya fakta bahwa media massa dikuasai oleh dominan swasta membuat terkadang konten menjadi tak berimbang, salah satuny adalah adominannya konten hiburan dan inimnya konten edukasi terutama edukasi dari sisi agama, apalagi dengan adanya keragaman agama di Indonesia serta dengan adanya dominasi mayoritas mengakibatkan ketimpangan konten dari sisi agama, yang mengakibatkan konten agama pada media massa di dominasi oleh konten - konten agama mayoritas. Melihat fenomena ini tentunya media massa menghadirkan implikasi baik implikasi positif maupun Implikasi negative dalam keterlibatannya membangun psikologi agama pada masyarakat. Berikut adalah dampak positif dan negative media massa terhadap tahap perkembangan psikologi agama pada manusia.

Dampak Positif dan Negatif Media Massa terhadap Perkembangan Psikologi Agama pada Manusia

A. Tahap Anak - anak a. Dampak Positif Media Massa

1. Media massa menyajikan berbagai program anak - anak pada tahun 90'an, berbagai acara itu dapat memicu perkembangan syaraf motorik anak. Sesuai dengan pembahasan diatas yang mana dijelaskan bahwa anak usia 3-6 tahun memiliki fase meniru perilaku sosok - sosok yang ada di sekitarnya, sehingga anak anak ini mampu meniru perilaku - perilaku baik dari tokoh yang termuah dalam media itu.

2. Adanya siaran lomba-lomba kreatifitas anak yang ditampilkan memunculkan motivasi anak untuk lebih kompetitif dalam berkreasi dan berkarya

\section{b. Dampak Negatif media massa}

1. Media massa kekinian yang didominasi oleh kepemilikan swasta mengedepankan agama mayoritas dalam setiap kontennya, hal ini baik bagi anak penganut agama mayoritas, namun bagi anak penganut agama minoritas mereka akan sangat kekurangan konten dalam media massa, sehingga tak jarang bagi anak yang kurang edukasi agama dari orang tuanya dan ahanya memanfaatkan media massa meniru perilaku keagamaan agama lain, inilah yang dapat menjadi awal pengikisan iman dan moral keagamaan bagi anak - anak.

2. Media massa kurang memiliki bahkan cenderung megurangi konten edukasi dan terkadang membaurkannya dengan konten dewasa, hal ini menyebabkan 
labilnya moral anak - anak. Tak jarang kita lihat bagaimana sex bebas telah merambah hingga pada anak - anak SD, inilah dampak dari kurang terfilternya konten - konten dewasa dalam media massa

\section{B. Tahap Remaja}

\section{a. Dampak Positif Media Massa}

1. Remaja merupakan masa peralihan dari anak - anak menuju dewasa, pada masa ini gejolak pubertas sedang menggebu, banyak remaja remaja yang sedang ingin menunjukkan eksistensinya, maka media massa dapat menjadi wadah berekspresi, misalkan dengan mengadakan pencarian bakat dalam seni budaya serta agama, hal ini tentu akan memberikan dorongan moril bagi peserta dan remaja penonton serta member sumbangsih pelestarian bagi budaya itu sendiri.

b. Dampak negative media massa

1. Remaja pada masa sekarang memiliki kecenderungan berkiblat pada sosok atau grup tertentu yang di labeli dengan stigma "kekinian" ditambah dengan promosi media baik itu media informasi maupun media social menjadikan para remaja kekinian ini mengikuti pola imitasi, atau meniru perilaku idolanya, dengan adanya proses imitasi ini, remaja seakan tergiring menikmati gemerlapnya dunia material dan mengesampingkan aspek - aspek spiritual dalam berkehidupan, selain itu juga institusi pendidikan yang menaungi remaja ini terkadang terpatok pada nilai dan kjurang mengapresiasi nilai - nilai moral, sehingga agama sendiri hanya cenderung hanya dijadikan pelengkap dalam kehidupan ini.

\section{Tahap Dewasa}

\section{a. Dampak Positif}

1. Masyarakat dewasa merupakan masyarakat yang matang dari sisi keagamaan, ideology yang tertanam pada diri masyarakat dewasa lebih mengakar kuat dibandingkan dengan remaja, media sendiri dalam rangka ini member penguatan -penguatan tambahan terhadap ideology keagamaan yang dianut.

2. Agama dengan budaya yang tinggi seperti Hindu kaya akan simbol dan perlu pemaknaan mendalam, media dalam hal ini berperan penting sebagai distributor pengetahuan tersebut, masyarakat seperti di Bali contohnya mengalami proses social bermasyarakat yang kompleks terumana dalam hal beragama, media dapat member konten pendidikan dan penguatan bagi keyakinan tersebut. Konten yang berisikan Dharma Wacana sangat bermanfaat sebagai sarana menjawab permasalahan permasalahan Umat, sehingga berkehidupan beragama lebih terasa manfaatnya.

\section{b. Dampak Negatif}

1. Keragaman media yang hadir kini memberi beragam opsi - opsi informasi tidak sedikit bahkan WIDYA DUTA | VOL. 16, NO. 1 |2021 
banyak media yang mengangkat tentang isu - isu agama dalam kontennya, alhasil masyarakat dapat menilai dan memebri pendapat linytas agama terhadap isu - isu hingga fenomena keagamaan, hal ini sebenarnya baik sebagai bahan koreksi, namun kematangan emosional masyarakat yang berbeda terkadang malah menyulut permasalahan misalnya saling menistakan dan saling menjelekkan agama. Hal inilah yang dapat memicu beragam masalah dalam bernegara, masyarakat dewasa yang telah mapan keyakinannya secara kekeh mempertahankan apa yang diyakini ketika berhadapan dengan umat lain, inilah yang cenderung menjadi friksi dalam kemasyarakatan layaknya perang di suriah, konflik rohingnya, semua hal itu bermula dari debat akan agama dan salah satunya bisa saja di sponsori oleh media massa.

D. Tahap Lanjutan

a. Dampak Positif

1. Sesuai dengan penjelasan sebelumnya, dinyatakan pada tahap lanjut ini, masyarakat yang berumur tua lebih mantap dalam hal beragama, adanya post power syndrome menjadikan ketakutan akan hal - hal yang berbau kematian semakin meningkat. Pada masa ini juga kecenderungan manusia merefleksikan diri meningkat, manusia mulai mengingat apa saja yang telah ia perbuat, mungkin merasa berdosa dan merasa tak layak memasuki surga. Disinalah peran media bermain, tayangan - tayangan meditasi, perenungan diri layaknya acara Gede Prama, membuat masyarakat pada usia lanjut mulai memaafkan dirinya, bepikiran positif hingga belajar mengendalikan emosi guna meningkatkan spiritual dalam diri.

Hal ini sangat membantu bagi masyarakat yang masih kaget akan penurunan performa tubuhnya, acara seperti ini menjadi penguat dan bagus menjadi bahan refleksi bagi kaum senior.

\section{b. Dampak Negatif}

1. Tak banyak dampak negatif yang bisa dihasilkan oleh media pada masyarakat lanjut usia, ketika masyarakat lanjut usia ini menyadari akan keberadaanya yang telah menua dan perlu merefleksikan diri, media cenderung di gunakan dan dipilah dalam rangka kebutuhan spiritual.

Demikianlah pemaparan tentang tahapan keberagaman seseorang dan bagaimana media massa member dampak pada perkembangan tersebut. Sebenaranya kehadiran media sangatlah baik selama mampu dipilah dan dipilih atas kebutuhan kita. Memilih konten sesuai umur dan memiliki kesetaraan pasti akan membuat kehidupan beragama menjadi lebih baik, namun selama media masih dominan dimiliki pihak swasta yang hanya mengejar rating, maka konten yang sehat masih sangat perlu diawasi, bukan hanya oleh pemeruintah melalui instansi terkaitnya melainkan dari pihak kita selaku masyrakat yang aktif 
memfilter dan melaorkan jika ada penayangan program yang memiliki konten menciderai kepribadian masyarakat.

\section{SIMPULAN}

Masyarakat dalam perkembangan psikologi keagamaan dapat terbagi dalam beberapa fase yaitu fase anak-anak, fase remaja, fase dewasa, dan fase lanjutan. Tiap fase memiliki karakteristik dan keunikan masing. Salah satu pembentuk karakter keberagamaan dalam fase - fase itu adalah media massa. Media massa di era sekarang bukan hanya sekedar pelengkap namun juga bagian dari hidup. Media inilah yang memiliki pengaruh baik positif maupun negatif bagi manusia.

\section{DAFTAR PUSTAKA}

Asmariani, Anak Agung Raka. 2010.

Buku Ajar Tata Susila Hindu. Denpasar : IHDN Denpasar.

Cangara, Hafied. 2003. Pengantar

IImu Komunikasi. Jakarta; PT RajaGrafindo Persada

Danim, Sudarwan. 2010.

Perkembangan Peserta Didik. Jakarta : Alfabeta

Jalaluddin, H, 2015, Psikologi Agama

Memahami perilaku dengan

Mengaplikasikan Prinsip-Prinsip

Psikologi. Jakarta: PT Raja Grafindo

Persada

Mc.Quail, Dennis. 1994. Teori

Komunikasi Massa. Jakarta; Erlangga

Moleong, L. J. 2014. Metodologi

Penelitian Kualitatif (Edisi Revisi). Bandung:

PT. Remaja Rosdakarya Offset.

Pudja, Gede dan Tjokorda Rai

Sudharta. 1973. Manava Dharmasastra

(Manu Dharmasastra). Surabaya : Paramita.
Tim Penyusun. 2005. Kamus Istilah Agama Hindu. Denpasar: Kantor Wilayah Departemen Agama Provinsi Bali

Titib, I Made. 2003. Menumbuh Kembangkan Pendidikan Budhi Pekerti pada Anak (Perspektif Agama Hindu). Bandung: Ganeca Exat Vivian,John.2008.Komunikasi Massa.Jakarta:Pranada Media Grup 